\title{
Anaerobic Digestion of Slaughterhouse Wastewater for Methane Recovery and Treatability
}

\author{
Zemene Worku ${ }^{1,2, *}$, Seyoum Leta ${ }^{2}$ \\ ${ }^{1}$ Department of Environmental Engineering, Addis Ababa Science and Technology University, Addis Ababa, Ethiopia \\ ${ }^{2}$ Center for Environmental Science, Collage of Natural and Computational Science, Addis Ababa University, Addis Ababa, Ethiopia
}

\section{Email address:}

hezeni@gmail.com (Z. Worku), letaseyoum@yahoo.com (S. Leta)

*Corresponding author

\section{To cite this article:}

Zemene Worku, Seyoum Leta. Anaerobic Digestion of Slaughterhouse Wastewater for Methane Recovery and Treatability. International Journal of Sustainable and Green Energy. Vol. 6, No. 5, 2017, pp. 84-92. doi: 10.11648/j.ijrse.20170605.13

Received: September 9, 2017; Accepted: September 22, 2017; Published: October 30, 2017

\begin{abstract}
The objective of this investigation was to optimize and evaluate the bioenergy production potential and COD removal efficiency of a semi-continuous anaerobic digester from slaughterhouse wastewater. The performance of the pilot scale anaerobic digester was evaluated at the OLRs of $0.32,0.51,1.16$ and $2.31 \mathrm{~kg} \mathrm{~m}^{-3} \mathrm{day}^{-1}$ under mesophilic environmental condition $\left(29.6 \pm 1.40^{\circ} \mathrm{C}\right)$. The COD removal efficiencies and methane yield in the pilot scale digester were in the range of 43.39 to $84.54 \%$ and $0.09 \pm 0.03$ to $0.22 \pm 0.02 \mathrm{~m}^{3} / \mathrm{kg}$ COD removed, respectively with the maximum volumetric methane production $\left(0.93 \pm 0.17 \mathrm{~m}^{3} /\right.$ day) was achieved at the OLR of $1.16 \mathrm{~kg} \mathrm{~m}^{-3} \mathrm{~d}^{-1}$ corresponding to an optimum methane yield of 0.20 $\mathrm{m}^{3} \mathrm{CH}_{4}$ per $\mathrm{kg}$ COD removed. Generally, the results of this study showed that anaerobic digester is efficient on generating bioenergy while treating high strength wastewater such as slaughterhouse wastewater. Hence, a full scale anaerobic digester should be developed and used to treat the wastewater generated in the slaughterhouse industries in Ethiopia where almost all the slaughterhouses discharge their wastewater to the nearby streams without prior treatment.
\end{abstract}

Keywords: Slaughterhouse Wastewater, Anaerobic Digester, Digester Performance, Methane Production and Yield, Gas Composition

\section{Introduction}

Meat production is increasing to fulfil the protein needs of the ever increasing world population which in turn has environmental pollution problems attached [5] due to the large quantities of wastewater generated from the slaughtering, processing and preserving activities required for meat production in municipal slaughterhouses. It is estimated that for every cow and pig processed, 700 and 330 liters of wastewater are generated, respectively, with an increase of $25 \%$ if further processing is carried out to produce edible products [12]. This wastewater is a complex mixture of compounds containing mainly organic materials with high concentration, a measured Chemical Oxygen Demand (COD) loading as high as 4,000-10,000 mg/l is typical for such wastewater $[9,10,13]$. It also contains high concentration of suspended solids, colloidal materials such as fats, proteins and cellulose [13].
Hence, the major environmental problem associated with this slaughterhouse wastewater is the large amount of organic matter or suspended solids and liquid waste as well as its odor generation released to the environment [18]. Effluent from slaughterhouses has also been recognized to contaminate both surface and groundwater due to the fact that blood, fat, manure, urine and meat tissues are lost to the wastewater streams during slaughter processing [22]. Blood, one of the major dissolved pollutants in slaughterhouse wastewater, has the highest COD of any effluent from abattoir operations [16]. If the blood from a single cattle carcass is allowed to discharge directly into a sewer line, the effluent load would be equivalent to the total sewage produced by 50 people on average day [6].

Slaughterhouse wastewaters, with the major characteristics of such high organic strength, sufficient organic biological nutrients, adequate alkalinity, relatively high temperature (20 to $30^{\circ} \mathrm{C}$ ) and free of toxic material, are well suited to anaerobic treatment and the efficiency in reducing the $\mathrm{BOD}_{5}$ 
ranged between 60 and 90\% [15] and from different research report point of view, it can be concluded that anaerobic digestion is a high-rate reactor which represents an attractive alternative for wastewater treatment at the slaughterhouse plant $[10,13]$.

Currently, most (if not all) slaughterhouses in Ethiopia discharges their wastewater directly into water bodies such as streams, rivers and lakes or municipal sewers systems, thereby putting these ecosystems at risk [2]. Addis Ababa abattoir enterprise (AAE), owning the largest slaughter house (Kera) in the country, releases its wastewater directly to the nearby stream without pretreatment. Lack of treatment systems at slaughterhouse facilities in Ethiopia is deeply rooted for the shortage of financial and technical resources associated with other factors, such as lack of governmental and societal pressures and a lack of knowledge of alternative practices impede the implementation of improved slaughterhouse wastewater management in Ethiopia (AAE, 2016). Given the direct release of wastewater with the pollutants to the environment, it is urgent to find a feasible and scientific solution to manage this slaughterhouse wastewater in Ethiopia in general and in Addis Ababa in particular. The main objective of this investigation was to evaluate and optimize the biogas production potential and COD removal efficiency of a semi-continuous anaerobic digester from slaughterhouse wastewater at mesophilic environmental temperature.

\section{Materials and Methods}

\subsection{Sources of Wastewater}

The slaughterhouse wastewater used as a substrate in this anaerobic digestion study was taken from Addis Ababa Slaughterhouse Enterprise (Kera), a municipal slaughterhouse located in the central part of Addis Ababa, Ethiopia. The word "Kerae is a name given to a place where edible animals are slaughtered. It is the biggest slaughterhouse in Ethiopia in which an average of more than 1000 head of cattle plus considerable numbers of small ruminants (goats and sheep) and rarely pigs are slaughtered [2]. Kera slaughterhouse uses large amount of water, estimated as more than $400.57 \mathrm{~m}^{3} /$ day for washing meat and cleaning processing areas. This large amount of water consumption leads to generate a significant amount of wastewater amounting about $363.35 \mathrm{~m}^{3} /$ day, which is directly discharged in to nearby Kera River without any prior treatment after it travels about 60 meters on land. Therefore, this pilot scale anaerobic digestion study was carried out in Addis Ababa Slaughterhouse (Kera) compound using $6 \mathrm{~m}^{3}$ dome shape anaerobic digester constructed underground.

\subsection{Digester Design}

A pilot-scale anaerobic digester was constructed underground using bricks in a dome shape with a dimension of 1.14 meter in height and 1.3 meter in diameter. The digester was constructed underground to enable the microbial biomass maintain the internal digester temperature in a stable manner regardless of the environmental temperature varies, so that no additional heating was needed during the during operation. The total volume of the digester was $6 \mathrm{~m}^{3}$, of which $5.1 \mathrm{~m}^{3}$ was working volume and the remaining volume dedicated for head space for gas. The wastewater inlet to the dome shape anaerobic digester was installed with a PVC pipe at the bottom, $20 \mathrm{~cm}$ from the bottom of the digester so that mixing of the digester system was performed with the up flow velocity of the inlet wastewater and no additional mixing was done. Figure 1 shows the schematic diagram of the pilot scale experimental setup.

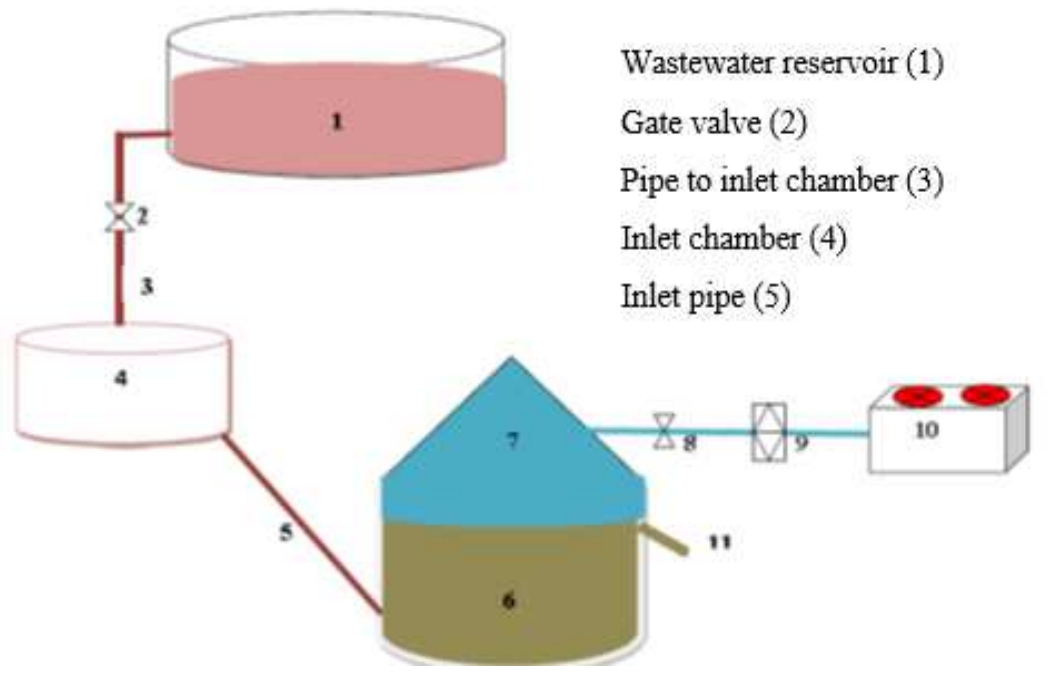

Digester (6)

Gas storage (7)

Gas valve (8)

Gas flow meter (9)

Biogas stove (10)

Effluent outlet (11)

Figure 1. Schematic diagram of the pilot scale experimental setup.

\subsection{System Operation}

Before using the slaughterhouse wastewater as a substrate, the digester was operated using fresh cow manure and rumen content for 60 days so as to establish the essential microbes in the digester. After two months of microbial establishment, 
the digester was fed with the slaughterhouse wastewater by operating at four different HRT, i.e., 22, 14, 6 and 3 days with the corresponding organic loading rate (OLR) as shown in Table 1.

Table 1. HRT, flow and organic loading rates used during the experimental period.

\begin{tabular}{llll}
\hline Phases & HRT & Flow Rate $(\mathbf{l} /$ day) & OLR $\left(\mathrm{kgCOD} / \mathbf{m}^{3}\right.$. day) \\
\hline 1 & 22 & 232 & 0.32 \\
2 & 14 & 364 & 0.51 \\
3 & 6 & 850 & 1.16 \\
4 & 3 & 1,700 & 2.31 \\
\hline
\end{tabular}

During the experimental period, the OLR in the digester was increased corresponding with decreasing HRT in order to allow microorganisms to adapt the changing environment. Then, the digester performance in terms of biogas production, methane yield and organic matter (COD) removal efficiency was evaluated during steady state of each phase. The digester was operated in semi-continuous mode by feeding once in every $24 \mathrm{hrs}$ interval for 6 months.

\subsection{Analytical Methods}

Measurement of physical parameter of the wastewater samples such as temperature and $\mathrm{pH}$ were conducted in situ at the time of sampling. Temperature was measured by digital thermometer and $\mathrm{pH}$ of the collected water samples were measured using $\mathrm{pH}$ meter (CON, 2700) with all the instruments got calibrated prior to taking readings.

Biochemical oxygen demand $\left(\mathrm{BOD}_{5}\right)$ and chemical oxygen demand (COD) were determined by titrimetric/volumetric methods whereas, total phosphate (TP), total nitrogen $(\mathrm{TN})$, ammonium $\left(\mathrm{NH}^{+4}-\mathrm{N}\right)$, sulfide $\left(\mathrm{S}^{2-}\right)$, and sulfate $\left(\mathrm{SO}_{4}{ }^{2-}\right)$ were measured by UV-Visible Spectrophotometer (Hack model DR/2400 portable spectrophotometer, Loveland, USA), all according to $\mathrm{HACH}$ instructions. Total solid (TS) and suspended solid (TSS) were also measured according to the methods described in standard methods of water and wastewater [4]. TDS and EC were measured using TDS/EC meter. The biogas production was measured using gas flow meter fitted on the gas pipeline installed from the dome of the digester and the biogas composition was determined using biogas analyzer (Geotechnical Instrument, UK, S/N BM-14068, England).

\subsection{Data Analysis}

The data generated from analytical method of each sample were statistically analyzed based on the objective of the study by organizing through MS-Excel spreadsheet. The graphs were drawn using Origin software, version 2017. The analysis of variance and comparison of means were performed on the data using IBM SPSS package version 23. The comparison between mean was performed at $5 \%$ level of significance.

\section{Result and Discussion}

\subsection{Characteristics of the Slaughterhouse Wastewater}

The average characteristics of the slaughterhouse wastewaters used in the studies are shown table 2 below. During sample collection, the lowest temperature mean value of the wastewater was $29.33 \pm 1.17^{\circ} \mathrm{C}$ and the highest mean value was $30.7 \pm 0.51^{\circ} \mathrm{C}$. The levels of $\mathrm{pH}$ were found in the range between $7.14 \pm 0.16$ and $7.23 \pm 0.27$ which indicates that the wastewater was neutral to slightly alkaline.

The concentrations of total dissolved solid and conductivity levels of the wastewater samples were considerably high with the range between $3,175.51 \pm 311.27$ to $3,737.74 \pm 628.32 \mathrm{mg} / \mathrm{l}$ and $1,803.25 \pm 86.43$ to $1,881.17 \pm 122.23 \mu \mathrm{Scm}^{-1}$, respectively (Table 2). Those values indicate that the slaughterhouse wastewater contained substantial dissolved (mobile) ions such as sulfate, nitrate, ammonium and other ions as depicted in the table below.

Table 2. Characteristics of the slaughterhouse wastewater used at four different OLR.

\begin{tabular}{|c|c|c|c|c|}
\hline Parameters & Phase I & Phase II & Phase III & Phase IV \\
\hline $\mathrm{pH}$ & $7.18 \pm 0.18$ & $7.22 \pm 0.25$ & $7.14 \pm 0.16$ & $7.23 \pm 0.27$ \\
\hline Temperature $\left({ }^{\circ} \mathrm{C}\right)$ & $30.7 \pm 0.51$ & $29.9 \pm 1.06$ & $29.33 \pm 1.17$ & $29.78 \pm 1.46$ \\
\hline E. C. $(\mu \mathrm{S} / \mathrm{cm})$ & $1803.25 \pm 86.43$ & $1881.17 \pm 122.23$ & $1870.61 \pm 118.21$ & $1843.82 \pm 148.70$ \\
\hline TS (mg/l) & $6205.53 \pm 685.78$ & $6545.07 \pm 519.69$ & $6033.31 \pm 293.48$ & $6163.96 \pm 582.94$ \\
\hline TSS (mg/l) & $2888.50 \pm 260.54$ & $2807.33 \pm 121.54$ & $2857.80 \pm 159.31$ & $2900.73 \pm 222.42$ \\
\hline TDS (mg/l) & $3317.03 \pm 612.58$ & $3737.74 \pm 628.32$ & $3175.51 \pm 311.27$ & $3263.23 \pm 646.42$ \\
\hline COD (mg/l) & $7049.07 \pm 306.42$ & $7079.69 \pm 226.89$ & $6975.77 \pm 178.44$ & $6942.59 \pm 152.98$ \\
\hline TKN (mg/l) & $565.16 \pm 54.91$ & $570.40 \pm 77.89$ & $584.84 \pm 61.77$ & $585.71 \pm 51.14$ \\
\hline $\mathrm{NH}_{4}{ }^{+}-\mathrm{N}(\mathrm{mg} / \mathrm{l})$ & $241.55 \pm 39.57$ & $226.65 \pm 12.33$ & $227.88 \pm 20.56$ & $223.17 \pm 26.85$ \\
\hline $\mathrm{TP}(\mathrm{mg} / \mathrm{l})$ & $152.33 \pm 16.75$ & $157.60 \pm 13.41$ & $154.19 \pm 12.52$ & $151.46 \pm 16.45$ \\
\hline Sulfide (mg/l) & $2.02 \pm 0.14$ & $2.10 \pm 0.15$ & $2.25 \pm 0.53$ & $2.10 \pm .10$ \\
\hline Sulfate (mg/l) & $569.85 \pm 58.10$ & $574.89 \pm 45.17$ & $567.31 \pm 46.73$ & $583.28 \pm 36.21$ \\
\hline
\end{tabular}

The slaughterhouse wastewater also contained huge amount of total and suspended solids with $6,033.31 \pm 293.48$ to $6,545.07 \pm 519.69 \mathrm{mg} / \mathrm{l}$ for TS and $2,807.33 \pm 121.54$ to $2,900.73 \pm 222.42 \mathrm{~g} / 1$ for TSS. Such elevated value of TS and TSS in the slaughterhouses wastewater could be attributed to various solid by-products such as animal feces, soft tissue removed during slaughtering and cutting, fats and soil from hides and hooves as well as the enormous amount of blood and urines released during slaughtering.

The mean organic matter content of the wastewater in this 
study was found extremely high with COD values ranging from $6,942.59 \pm 152.98$ to $7,079.69 \pm 226.89 \mathrm{mg} / \mathrm{l}$. The wastewater also contained high amount of nitrogenous and phosphate compounds with concentrations of TKN found between $565.16 \pm 54.91$ to $585.71 \pm 51.14 \mathrm{mg} / \mathrm{l}$ and total phosphate $151.46 \pm 16.45$ to $157.60 \pm 13.41 \mathrm{mg} / \mathrm{l}$. Similarly, the sulfate and sulfide concentrations were found in the range between $567.31 \pm 46.73$ to $583.28 \pm 36.21 \mathrm{mg} / 1$ and $2.10 \pm .10$ to $2.25 \pm 0.53 \mathrm{mg} / \mathrm{l}$, respectively. Abrha and Tenalem [1] reported relatively higher COD and solid contents in the same slaughterhouse plant.

As can be computed from the table, the $\mathrm{COD} / \mathrm{SO}_{4}{ }^{-2}$ ratio laid between 11.9 and 12.4. The highest ratio was observed in the influent used in the last phase of the study. Researches confirmed that there would be vigorous competition between the methane producing bacteria and sulfur reducing bacteria if the COD/sulfate ratios are between $1.7-2.7$ and sulfate reducing bacteria would be more competitive at lower $\mathrm{COD} / \mathrm{SO}_{4}{ }^{-2}$ ratios, below 1.5 [21]. However, the ratios of $\mathrm{COD} / \mathrm{SO}_{4}{ }^{-2}$ were greater than 11 in all the feeding used in the four different phases of the present study. These levels of ratio support effective performance of the anaerobic digester in both COD removal and increase biogas yield [20] as methane gas generation is directly proportional to the removal of organic matter (COD) through the action of anaerobic bacteria and methanogenic activity increase with decreasing sulfate concentration.

\subsection{Digester Performance}

The performance of the pilot scale anaerobic digester, in terms of organic matter removal efficiency, biogas production, methane production and yield, has been investigated for the four phases of the study attributed to the different organic loading rate (OLR) in tropical environmental conditions with an average digester temperature of $29.6 \pm 1.40^{\circ} \mathrm{C}$.

\subsubsection{Biogas and Methane Production}

The trends in the volumetric biogas and methane $\left(\mathrm{CH}_{4}\right)$ production during all the experimental phases are illustrated in Figure 2 below. The average biogas and methane production during phase 1 (at $\mathrm{OLR}=0.32 \mathrm{~kg} \mathrm{~m}^{-3} \mathrm{~d}^{-1}$ with $\mathrm{HRT}=22$ days) was $0.42 \pm 0.02 \mathrm{~m}^{3}$ and $0.31 \pm 0.02 \mathrm{~m}^{3}$ per day, respectively. As the organic loading rate increases in phase 2 and 3 through decreasing the HRT in to 14 and 6 days respectively, the biogas and $\mathrm{CH}_{4}$ generation were also increased with the highest in phase 3 (at OLR $=1.16 \mathrm{~kg} \mathrm{~m}^{-3} \mathrm{~d}^{-1}$ ). However, when the OLR increases from $1.16 \mathrm{~kg} \mathrm{~m}^{-3} \mathrm{~d}^{-1}$ (phase 3) to $2.31 \mathrm{~kg} \mathrm{~m}^{-3} \mathrm{~d}^{-1}$ (phase 4) with further reduction of the HRT to 3 days only, a sharp falling of both biogas and $\mathrm{CH}_{4}$ production were observed.

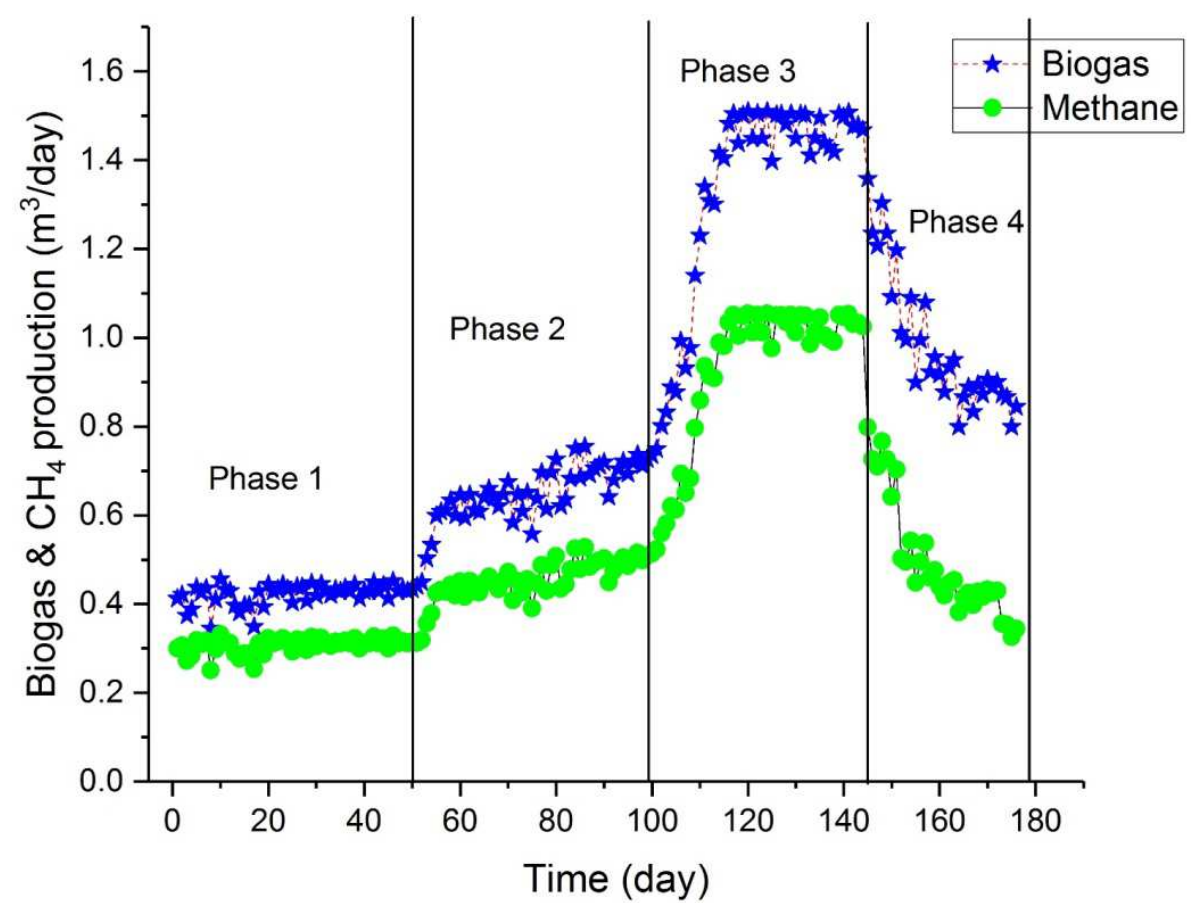

Figure 2. Volumetric Production of Biogas and Methane at different organic loading rate.

As indicated in table 2, significantly higher biogas and $\mathrm{CH}_{4}$ generation $(\mathrm{p}<0.05)$ were observed in phase 2 and 3 compared to phase 1 attributed to the increased organic loading rate. However, when the OLR increases from $1.16 \mathrm{~kg}$ $\mathrm{m}^{-3} \mathrm{~d}^{-1}$ (phase 3) to $2.31 \mathrm{~kg} \mathrm{~m}^{-3} \mathrm{~d}^{-1}$ (phase 4), the production of both biogas and $\mathrm{CH}_{4}$ were significantly reduced $(\mathrm{p}<0.05)$ compared to phase 3 . Hence, significantly highest biogas and methane generations $(\mathrm{p}<0.05)$ were observed in phase 3 $\left(1.33 \pm 0.25 \mathrm{~m}^{3}\right.$ biogas and $0.93 \pm 0.17 \mathrm{~m}^{3} \mathrm{CH}_{4}$ generated per day). A total volume of $143.94 \mathrm{~m}^{3}$ biogas and $95.15 \mathrm{~m}^{3}$ methane were generated during the entire study period (about 6 months).

The present study shows that biogas and $\mathrm{CH}_{4}$ generations were low at the beginning of the experiment (phase 1) due to 
the insufficient organic matter to be converted to biogas resulted in the maximum utilization of the substrate by microorganisms during the long substrate retention time [11].

Then after, the volumetric biogas and methane productions were increased with increasing organic loading rate from
0.32 to $1.16 \mathrm{~kg} \mathrm{~m}^{-3} \mathrm{~d}^{-1}$, showing strong linear correlations $\left(\mathrm{R}^{2}=0.95\right)$ as shown in figure 3 . Since, the slopes of the lines are positive, the gas production is positively correlated and increased with increasing organic loading rate from phase 1 to phase 3 .

Table 3. Summary of the pilot scale anaerobic digester performance.

\begin{tabular}{|c|c|c|c|c|}
\hline Parameters & Phase 1 & Phase 2 & Phase 3 & Phase 4 \\
\hline OLR, kg.m ${ }^{-3} \cdot$ day $^{-1}$ & $0.32 \pm 0.01$ & $0.51 \pm 0.01$ & $1.16 \pm 0.03$ & $2.31 \pm 0.05$ \\
\hline HRT, day & 22 & 14 & 6 & 3 \\
\hline COD in, kg.day ${ }^{-1}$ & $1.63 \pm 0.06$ & $2.57 \pm 0.08$ & $5.93 \pm 0.15$ & $11.80 \pm 0.26$ \\
\hline COD removal, $\%$ & 84.54 & 82.82 & 77.92 & 43.39 \\
\hline COD removed, kg.day ${ }^{-1}$ & $1.38 \pm 0.05$ & $2.13 \pm 0.06$ & $4.62 \pm 0.20$ & $5.12 \pm 0.20$ \\
\hline Biogas production, $\mathrm{m}^{3}$.day ${ }^{-1}$ & $0.42 \pm 0.02$ & $0.65 \pm 0.0 .07$ & $1.33 \pm 0.25$ & $0.98 \pm 0.15$ \\
\hline Methane, $\%$ & 72.75 & 70.15 & 69.86 & 49.54 \\
\hline Methane yield, $\mathrm{m}^{3} \mathrm{~kg}^{-1} \mathrm{CODr}$ & $0.22 \pm 0.02$ & $0.21 \pm 0.02$ & $0.20 \pm 0.04$ & $0.09 \pm 0.03$ \\
\hline $\mathrm{CO}_{2}, \%$ & 20.52 & 23.20 & 25.30 & 42.33 \\
\hline $\mathrm{pH}$ & $7.60 \pm 0.40$ & $6.75 \pm 0.29$ & $6.73 \pm 0.29$ & $5.00 \pm 0.78$ \\
\hline
\end{tabular}

This revealed that the microbial biomass in the digester was continuously acclimatizing to the changing environmental conditions created due to the increased OLR
$[3,8]$. In addition, it was observed that the digester was stable from phase 1 through phase 3 substantiated by the normal range of $\mathrm{pH}$ measured daily (table 2 ).

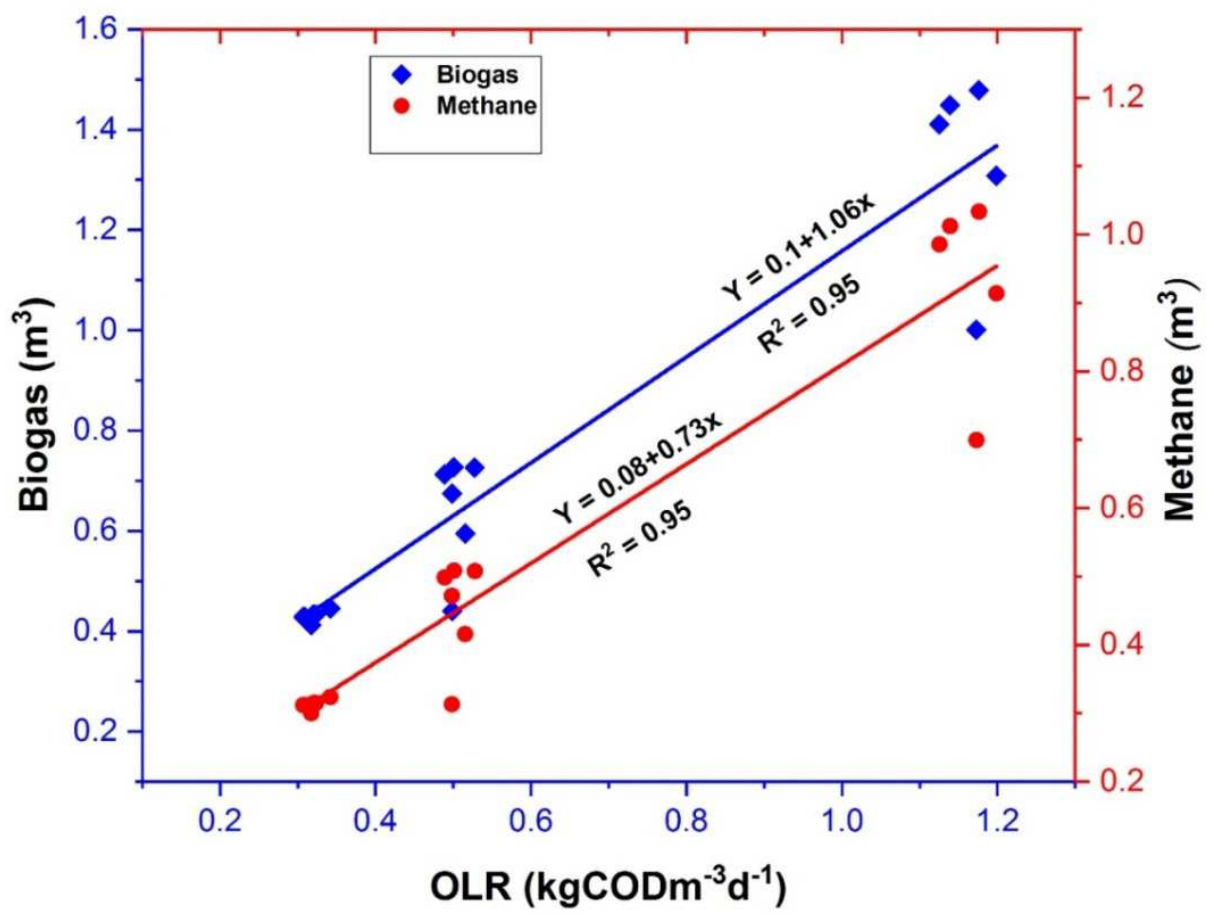

Figure 3. Biogas and methane generations as a function of organic loading rate (OLR).

On the other hand, as the OLR increased from $1.16 \mathrm{~kg} \mathrm{~m}^{-}$ ${ }^{3} \mathrm{~d}^{-1}$ to $2.31 \mathrm{~kg} \mathrm{~m}^{-3} \mathrm{~d}^{-1}$ in terms of COD (phase 4), the volumetric biogas and methane generations significantly reduced $(\mathrm{p}<0.05)$ compared to phase 3 of the study. This might be due to the inadequate HRT period at the corresponding increased OLR values which was not sufficient for the microbial biomass to convert the substrate to biogas and methane [3]. The digester was also observed unstable as the $\mathrm{pH}$ drops to 5 .

\subsubsection{Gas Composition and Methane Yield}

The average biogas generation during phase 1 (at
OLR $=0.32 \mathrm{~kg} \mathrm{~m}^{-3} \mathrm{~d}^{-1}$ ) was $0.42 \pm 0.02 \mathrm{~m}^{3}$ per day with the $\mathrm{CH}_{4}$ and $\mathrm{CO}_{2}$ compositions were $72.75 \%$ and $20.52 \%$, respectively, resulted in an average $0.31 \pm 0.02 \mathrm{~m}^{3}$ methane produced per day. Relatively higher methane yield was also recorded in phase $1\left(0.22 \pm 0.02 \mathrm{CH}_{4}\right.$ per $\mathrm{kg}$ of COD reduced) due to higher percentage of methane content in the biogas generated. When the organic loading rate increases from 0.32 to 0.51 and $1.16 \mathrm{~kg} \mathrm{~m}^{-3} \mathrm{~d}^{-1}$ in phase 2 and 3 , a slight decrease in the methane content was observed $(70.15 \%$, and $69.86 \%$ in phase 2 and 3, respectively) with an increase in the $\mathrm{CO}_{2}$ content of the biogas $(23.2 \%$ and $25.3 \%)$. However, there was no significant difference in the average $\mathrm{CH}_{4}$ yield 
obtained in phase 2 and $3(p>0.05)$ compared to phase 1 (table 3 and figure 4).

On the other hand, when the OLR increases beyond 1.16 $\mathrm{kg} \mathrm{m} \mathrm{m}^{-3} \mathrm{~d}^{-1}$, the $\mathrm{CH}_{4}$ content and yield were significantly reduced $(\mathrm{p}<0.05)$ and the composition of $\mathrm{CO}_{2}$ was increased with the $\mathrm{CH}_{4}$ and $\mathrm{CO}_{2}$ composition were $49.54 \%$ and $42.33 \%$, respectively, resulted in significantly lowest methane yield generation $(\mathrm{p}<0.05)$ of all the study phases (only $0.09 \pm 0.03 \mathrm{~m}^{3} \mathrm{CH}_{4}$ was generated per $\mathrm{kg}$ COD reduced). Sindhu and Meera [19] reported lower methane yield $\left(0.17 \mathrm{~m}^{3} \mathrm{CH}_{4}\right.$ per $\mathrm{kg}$ COD reduced) than phase 1,2 and 3 of the present study from the treatment of slaughterhouse wastewater using an up flow anaerobic sequencing batch reactor. The methane yield obtained in phase 1,2 and 3 of this study is comparable with results reported by Raj et al. [17] from the treatment of slaughterhouse wastewater using anaerobic sequencing batch reactor.

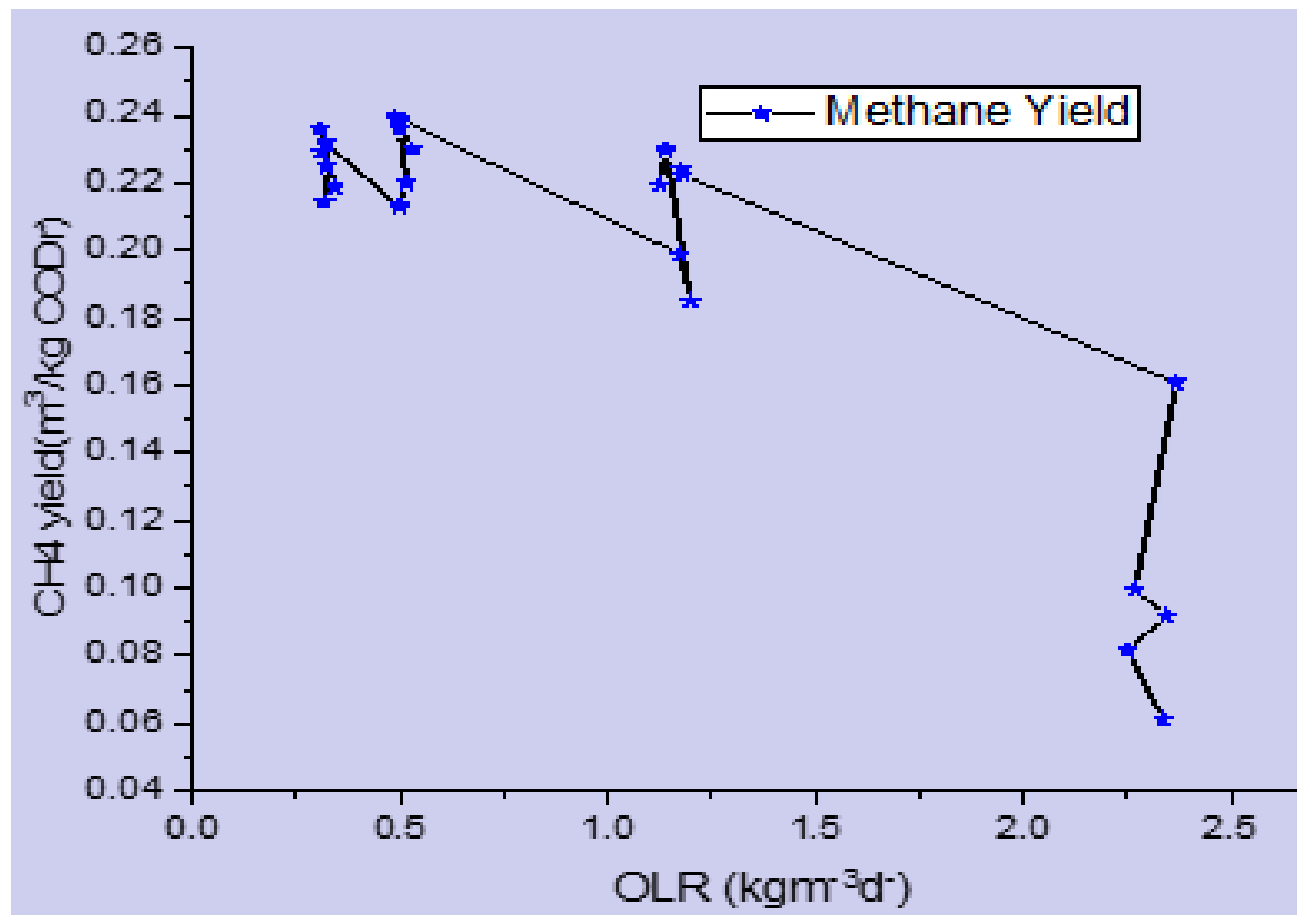

Figure 4. Methane yield as function of organic loading rate.

However, the methane yields obtained in this study were lower than the results recorded by Masse and Masse [9] from the treatment of slaughterhouse wastewater $\left(0.49 \mathrm{~m}^{3} \mathrm{CH}_{4} / \mathrm{kg}\right.$ COD removed) using anaerobic sequencing batch reactor.

\subsubsection{COD Removal Efficiency}

COD was used as a major parameter to compare the performance of the digester and to monitor the effect of OLR throughout the study phases. As can be seen from Figure 5, the digester showed a stable behavior from phase 1 to phase 3 (up to an OLR of $1.16 \mathrm{~kg}$ COD m$~^{-3}$ day $^{-1}$ ) with a slight decrease in the COD removal efficiency.

During the first phase of the operation, the average COD removal efficiency and mass removal rate were $84.54 \%$ and $1.38 \pm 0.05 \mathrm{~kg}$ COD per day, respectively resulting in $1,086.17 \mathrm{mg} / 1$ of COD in the effluent. In the second phase, the average COD removal efficiency was $82.82 \%$ with an average organic mass removal rate of $2.13 \pm 0.06 \mathrm{~kg}$ COD per day while the average concentration of COD in the digester effluent was $1,211.66 \mathrm{mg} / \mathrm{l}$. In the third phase, the average COD removal efficiency was decreased to $77.92 \%$ while the organic mass removal rate was $4.62 \pm 0.20 \mathrm{~kg}$ COD per day leaving $1,538.50 \mathrm{mg} / \mathrm{l}$ of $\mathrm{COD}$ in the final effluent. In the final phase (4), the COD removal efficiency was significantly decreased $(\mathrm{p}<0.05)$; only about $43.39 \%$ of the COD was removed but the mass removal rate was $5.12 \pm 0.20 \mathrm{~kg}$ COD per day leaving more than $56 \%(3,931.77 \mathrm{mg} / \mathrm{l})$ of the COD concentration in the effluent.

The COD removal efficiency in phase 1 was slightly higher than that of phase $2 \& 3$ and the COD removal efficiency in phase 1,2 and 3 were significantly higher than the COD removal efficiency in phase $1(\mathrm{p}<0.05)$. The major cause for this is that simple organic compounds produced in the hydrolysis are further converted in to volatile fatty acids by acidogenic bacteria and these intermediary compounds are changed to acetic acid, carbon dioxide and hydrogen in the acetogenic stage which are substrate for the methanogenic bacteria use this molecule to produce methane and carbon dioxide as end product [14]. Hence, increasing feeding time would cause a decrease in volatile fatty acids (VFA) which could reduce the substrate availability to microorganism and cause low accumulation of these acids in the reactor. This in turn increases the COD removal efficiency [7]. 


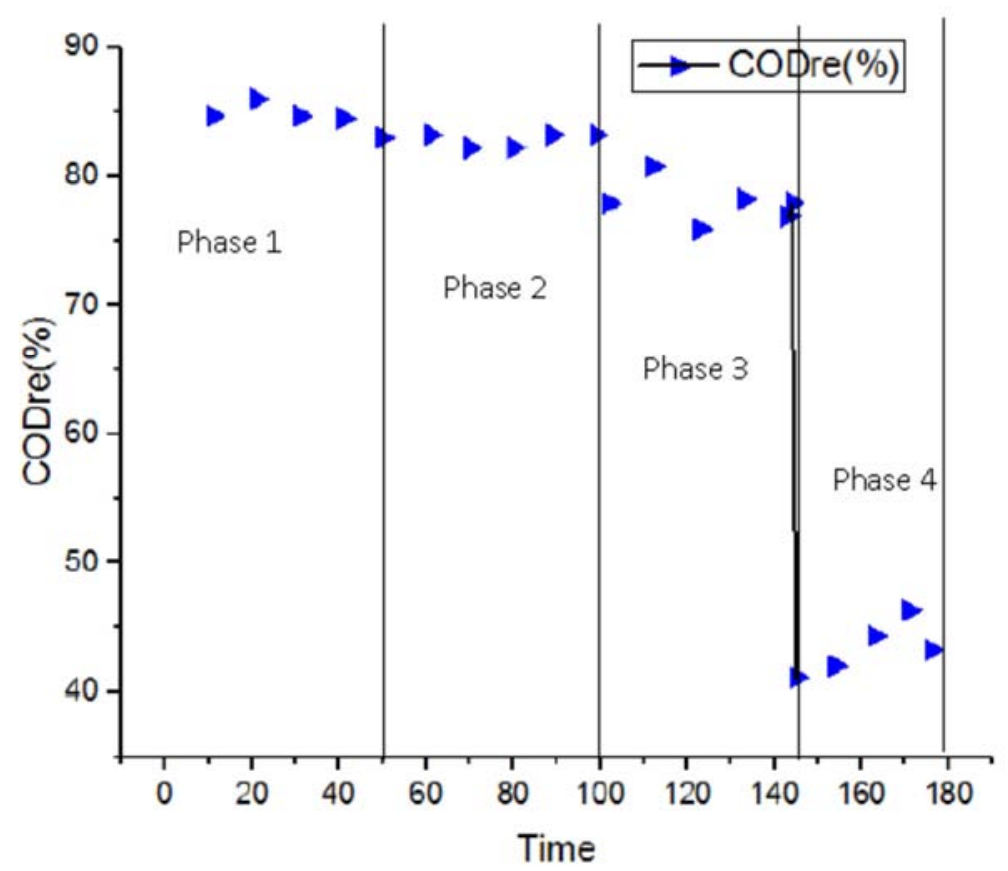

Figure 5. COD removal efficiency at different organic loading rate.

On the other hand, the COD removal efficiency was significantly lower in phase $4(\mathrm{p}<0.05)$ due to insufficient time for the microbial biomass to convert the organic substrate to the intermediate compounds and further to methane and carbon dioxide due to the short HRT.

As revealed from figure 6, the COD removal efficiency significantly negatively correlated with mass removal rate with increasing of organic loading rate $(p<0.05$; Pearson Correlation $=-0.92)$. The organic matter mass removal rate was significantly strongly associated with increasing of organic loading rate $(\mathrm{p}<0.05$; pereason correlation $=0.99)$. Moreover, Figure 6 also shows the linear relationship between mass removal rates and organic loading rate and hence, mass COD removal rate highly depends on organic loading rate if the biomasses in the digester have sufficient time to utilize the waste (Song et al., 2003). The COD removal efficiency of the first phase was not significantly different from phase $2(p>0.05)$ and significantly higher than the other two phases $(\mathrm{P}<0.05)$. The removal efficiency in the second phase was also higher than phase three and four and removal efficiency in phase four was significantly lower than all the three phases of the operation $(p<0.05)$. Hence, the COD removal efficiency decreased with increasing of organic loading rate (Figure 6). This might be attributed to the accumulation of VFA due to the reduction of hydraulic retention time (HRT) in the anaerobic reactor.

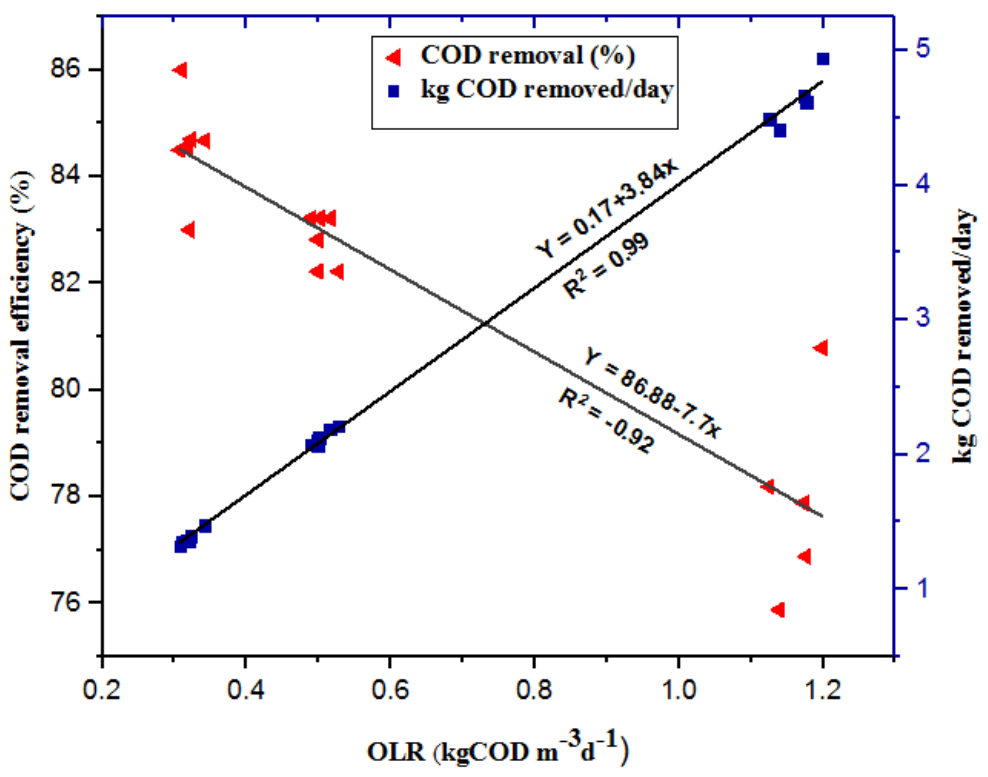

Figure 6. COD removal efficiency and mass removal rate with organic loading rate. 


\section{Conclusion}

The performance of the pilot scale anaerobic digester was evaluated at the OLRs of $0.32,0.51,1.16$ and $2.31 \mathrm{~kg}$ $\mathrm{m}^{-3}$ day $^{-1}$ under mesophilic environmental condition $\left(29.6 \pm 1.40^{\circ} \mathrm{C}\right)$. The COD removal efficiencies and methane yield in the pilot scale digester were in the range of 43.39 to $84.54 \%$ and $0.09 \pm 0.03$ to $0.22 \pm 0.02 \mathrm{~m}^{3} / \mathrm{kg}$ COD removed, respectively with the maximum volumetric methane production $\left(0.93 \pm 0.17 \mathrm{~m}^{3} /\right.$ day $)$ was achieved at the OLR of1.16 $\mathrm{kg} \mathrm{m}^{-3} \mathrm{~d}^{-1}$ corresponding to an optimum methane yield of $0.20 \mathrm{~m}^{3} \mathrm{CH}_{4}$ per $\mathrm{kg} \mathrm{COD}$ removed. Hence, the results of this study showed that COD removal efficiency, methane percentage and yield were decreased with increasing OLR or decreasing HRT. However, the volumetric biogas and methane generations increase with increasing OLR up to a certain point and then decrease, with the highest volumetric biogas and methane productions obtained at the OLR of 1 . $16 \mathrm{kgm}^{-3} \mathrm{~d}^{-1}$ (phase 3 ) and the lowest was obtained at OLR of 2. $31 \mathrm{~kg} \cdot \mathrm{m}^{-3} \mathrm{~d}^{-1}$ (phase 4 ). It can be also concluded that anaerobic digester was efficient on generating biogas and removing the organic matter thereby treating strong agroindustrial effluents such as slaughterhouse wastewater with optimum bioenergy production and COD removal efficiency took place at OLR of $1.16 \mathrm{~kg} \cdot \mathrm{m}^{-3} \mathrm{~d}^{-1}$ at HRT of 6 days.

\section{Acknowledgements}

The authors would like to thank Ministry of Water, Irrigation and Electricity of Ethiopia for financing this research. We also extend our gratitude to Center for environmental sciences, Addis Ababa University and Addis Ababa Abattoir enterprise for their technical and laboratory support.

\section{References}

[1] Abrha Mulu and Tenalem Ayenew (2015). Characterization of Abattoir Wastewater and Evaluation of the Effectiveness of the Wastewater Treatment Systems in Luna and Kera Abattoirs in Central Ethiopia, International Journal of Scientific \& Engineering Research, Volume 6, Issue 4, pp. 1026-1039.

[2] Addis Ababa Abattoir Enterprise (2016). Annual Company Report, June 2016, Addis Ababa, Ethiopia.

[3] Andualem Mekonnen, Seyoum Leta and Karoli Nicholas Njau (2017). Anaerobic treatment of tannery wastewater using ASBR for methane recovery and greenhouse gas emission mitigation, Journal of Water Process Engineering, Volume 19, pp. 231-238.

[4] APHA, AWWA, WEF, Standard Methods for the Examination of Water and Wastewater, 22nd ed., Washington DC, 2012.

[5] O. Akinro, I. B. Ologunagba, and O. Yahaya (2009). Environmental implications of unhygienic operation of a city abattoir in Akure, Western Nigeria, ARPN Journal of Engineering and Applied Sciences, vol. 4, no. 9, pp. 311-315.
[6] A. O. Aniebo, S. N. Wekhe, andI. C. Okoli (2009). Abattoir blood waste generation in rivers state and its environmental implications in the Niger Delta, Toxicological and Environmental Chemistry, vol. 91, no. 4, pp. 619-625.

[7] Bagley D. M. and Brodkorb T. S. (1999). Modeling microbial kinetics in an anaerobic sequencing batch reactor-model development and experimental validation, Water Environmental Research 71: 1320.

[8] Borja R., Charles J. B., Wang Z. and Mancha A. (1998). Anaerobic digestion of slaughterhouse wastewater using combination sludge blanket and filter arrangement in a single reactor. Bioresourcr Technology vol. 65,125-133.

[9] D. I. Masse' and L. Masse (2000). Treatment of slaughterhouse wastewater in anaerobic sequencing batch reactors, Canadian Agricultural Engineering, vol. 42, no. 3, pp. 131-137.

[10] Edith Padilla-Gasca, Alberto López-López and Juan GallardoValdez (2011). Evaluation of Stability Factors in the Anaerobic Treatment of Slaughterhouse Wastewater, $J$ of Bioremed Biodegrad.

[11] K. Kavitha, A. G. Murugesan (2007). Efficiency of Upflow anaerobic granulated sludge blanket reactor in treating fish processing effluent, J. Ind. Pollut. Control 23 (1), pp. 77-92.

[12] López-López A, De la Barrera-Fraire J, Vallejo-Rodriguez R, Barahona-Argueta C (2008) Estudio comparativo entre un proceso fisicoquímico y uno biológico para tratar agua residual de rastro. Interciencia 33: 490-496.

[13] Maria Octoviane Dyan, Gita Permana Putra, Budiyono, Siswo Sumardiono, and Tutuk Djoko Kusworo (2015). The effect of $\mathrm{pH}$ and operation mode for COD removal of slaughterhouse wastewater with Anaerobic Batch Reactor, Waste Tech. Vol.3(1).

[14] M. H. Gerardi, The Microbiology of Anaerobic Digesters. Wastewater Microbiology Series, John Wiley and Sons Inc, New Jersey, USA, 2003.

[15] O. Chukwu (2008). Analysis of groundwater pollution from abattoir Waste in Minna, Nigeria, Research Journal of Diary Science, vol.2, pp. 74-77.

[16] Pradyut Kundu, Anupam Debsarkar and Somnath Mukherjee (2013). Treatment of Slaughter House Wastewater in a Sequencing Batch Reactor: Performance Evaluation and Biodegradation Kinetics, BioMed Research International, Volume 2013, Article ID 134872, 11 pages, Accessed from http://dx.doi.org/10.1155/2013/134872.

[17] R. Rajakumar, T. Meenambal, P. M. Saravanan, and P. Ananthanarayanan (2012). Treatment of poultry slaughterhouse wastewater in hybrid upflow anaerobic sludge blanket reactor packed with pleated poly vinyl chloride rings, Bioresource Technology, vol. 103, no. 1, pp. 116-122.

[18] S. M. Gauri (2006). Treatment of wastewater from abattoirs before land application: a review, Bioresource Technology, vol. 97, no. 9, pp. 1119-1135.

[19] Sindhu R and Meera V. (2012) Treatment of Slaughterhouse Effluent Using Upflow Anaerobic Packed Bed Reactor. International Congress on Informatics, Environment, Energy and Applications-IEEA 2012 IPCSIT vol.38. 
[20] S. Venkata Mohan, N. C. Rao, K. K. Prasad, P. N. Sarma, Bioaugmentation of an anaerobic sequencing batch biofilm reactor (An SBBR) with immobilized sulphate reducing bacteria (SRB) for the treatment of sulphate bearing chemical wastewater, Process Biochem. 40 (2005) 2849-2857.

[21] T. Y. Jeong, G. Cha, Y. C. Seo, C. Jeon, S. S. Choi (2008). Effect of $\mathrm{COD} /$ sulfate ratios on batch anaerobic digestion using waste activated sludge, J. Ind. Eng. Chem. 14, 693-697.
[22] Y. O. Bello and D. T. A. Oyedemi (2009). Impact of abattoir activities and management in residential neighbourhoods: a case study of Ogbomoso, Nigeria, Journal of Social Science, vol. 19, pp. 121-127.

[23] Z. Song, C. J. Williams, R. G. J. Edyvean (2003). Tannery wastewater treatment using an upflow anaerobic fixed biofilm reactor (UAFBR), Environ. Eng. Sci. 20 (6). 